\title{
The Prospects for Socialist Politics in South Africa
}

\section{Global and Domestic Trends Following the Failed SRWP Experiment}

\author{
Giovanni Poggi and Ongama Mtimka
}

\begin{abstract}
Our article endeavours to critically examine the prospects for socialist parties and socialist policy reform in South Africa. Firstly, we seek to provide an appraisal of modern socialist politics and policies globally. Secondly, we attempt to diagnose why South Africa has been as yet unable to fashion a suitable socialist workers' party during the democratic epoch. In this, the article discusses the prospects of socialist parties and policy reform in South Africa after examining the failure of the Socialist Revolutionary Workers' Party (SRWP) to make an impact at the 2019 polls. Using a combination of comparative methodology and critical inquiry, our study presents not only that socialist politics and policies are valuable to democratic systems, but also that socialist politics should have a more viable vehicle in South Africa. The prospects for deepened ideological development, particularly the formation of a successful socialist or workers' party, remains quite weak in South Africa but there is considerable evidence to suggest that civil society both requires and desires a more vibrant relationship with modern socialism.
\end{abstract}

Keywords: comparative politics, democracy, democratic socialism, electoral politics, ideology, precolonial, social democracy, socialism, workers' parties

The National Union of Metal Workers of South Africa (NUMSA) finally put its resolution to form a workers' party to the test in December 2018 and contested the country's sixth national election 
during the 2019 national general election period. NUMSA formed the Socialist Revolutionary Workers' Party (SRWP) with much fanfare on what may be considered the eve of the elections. Its secretary general, Irvin Jim, was appointed leader of the party while retaining his position in the union. It was fashioned as the ultimate representative of the working class in South Africa that would be able to deliver a socialist orientated state. It would counter the African National Congress (ANC) that NUMSA saw as having succumbed to the dictates of the South African bourgeoisie led by its billionaire president Cyril Ramaphosa. The move followed a six year period in which NUMSA appeared incapable of translating the resolution of its twelfth general conference in 2013 into reality, given what appeared to be confusion about what it meant practically and how to implement it (Mtimka 2016).

Prior to the 2019 elections, the NUMSA-aligned United Front, which was expressly regarded as a broad social movement in the fashion of the anti-apartheid United Democratic Front and not the workers' party, ended up contesting local elections through what was regarded as 'affiliated organisations' in the 2016 local government election. It had presence mainly in the Eastern Cape and contested elections when there were still internal debates within NUMSA, regarding which of the resolutions to form a broad movement and a political party the initiative was fulfilling. When the 2019 elections were over, the union and the party appeared to be extremely disappointed with their results. Jim suggested that the party had been robbed of its votes by a corrupt electoral commission. 'Getting so many votes for the SRWP is a joke' he exclaimed in disbelief while taking post-election questions from the media on prospects of challenging the election outcome.

This article reflects critically on the prospects for creating a viable socialist leaning political vehicle in South Africa. In this, it presents and reviews global trends in the evolution of socialist politics, whilst also using the experience of the Socialist Revolutionary Workers' Party in the 2019 national general elections as a point of reference for South Africa. We reflect on the state of socialist parties and policies globally since the turn of the twenty-first century, and reflect on the trajectory of socialist and leftist politics in South Africa. We regard social democratic parties as those that base themselves on workers' rights, dignified employment, and fair 
wages; while also seeking to provide decent national healthcare, equal education and literacy; as well as some form of social security or welfare, redistribution, collective ownership and environmental consciousness (de la Torre 2017; Baradat and Phillips 2017; Ellner 2019). The approach lends itself within the discipline of comparative politics using political parties and their corresponding national and sub-national systems as units of analysis. Because NUMSA drew its inspiration largely from the Workers' Party in Brazil, also formed by metalworkers, Brazil and other Latin American cases enjoy considerable focus in the comparative approach employed.

The key claim of this article is that modern socialist leaning parties and policies offer valuable alternatives for developing countries that struggle to reduce socio-economic inequality. South Africa is a great candidate for this type of political stance. The other key claim is that while South Africa appears to be ripe for authentic leftleaning politics and policies, neither the SRWP, nor any other party, has yet been able to provide a suitable vehicle to convince South Africans to vote for a democratic socialist movement.

\section{The Evolution and Democratisation of Socialism in the Modern Era}

Socialist policy and application in the twenty-first century is fundamentally not the same as Stalin's Soviet Union or Mao's China. Suggestions to the contrary seek to diminish political opposition to neoliberal democracy. Indeed, the history of the twentieth century was not kind to the prospects for socialist reform in the modern era. The unfortunate story told of Marxist-Leninism has been one of (often-violent) repression and authoritarianism, notwithstanding the apparent commitment to this version of leftist political economy among some politicians and trade unionists. Many of the twentieth century one-party orientations utilised the Marxist-Leninist tradition of a ruling vanguard (Geoghegan and Wilford 2014; Baradat and Phillips 2017). The consequences of vanguardism left the idea of free civil society decimated in countries where Marxist-Leninist orientations drove governance and policy creation. The emphasis on state centralisation of the economy, as well as strict sociopolitical control over the subjugated in orthodox communist states 
proved to be unsustainable as the century progressed. Most of the literature we encounter today hereafter paints Marxist-Leninism as a vilified regime format with substantial historical backing.

With the ammunition of recent history, methods of ideological suppression are typically found in the United States, as seasoned neoconservative politicians often explain away left-aligned policy as a poorly dressed up version of Marxist-Leninism (Drier 2019). The emphasis in this process is to narrow the 'ideological window' of what any given society would deem as acceptable or appropriate politics. This Overton window, named after Joseph Overton, is squashed in order to label any opinion outside of moderate or centrist politics as radical, inappropriate or even abhorrent (Lehman 2012; Maza 2017). By succeeding in this endeavour, socialist policy ideas can be easily tossed out of the realm of acceptable discussion. As a result, in the case of the United States since the coming to prominence of Bernie Sanders and Alexandria Ocasio-Cortez, socialist policy initiatives have been equated disparagingly with the 'still looming' threat of communism. However, with the recent electoral capture of the executive office of Joseph Biden, perhaps more compromise may be found between the Sanders' camp and Biden's more moderate camp in US policy-making.

Contrary to the dominant narrative on the 'threat of communism' in liberal democracies, factual evidence illustrates a discernible evolution of socialist parties and policy initiatives over time. In the next section we make mention of a range of socialist parties and social policy-making that have been successfully established within modern democratic norms. There has certainly been an evolution over time towards socialist reform that does not seek to simultaneously quash political and civil liberties. For comparative context, it is perhaps fair to point out that in the case of South Africa, the expression of left-wing rhetoric in broader society has not been supressed as heavily as in the United States. The African National Congress (ANC), the primary entity responsible for the democratic transition in South Africa, was deeply rooted in left-wing politics before the decline of the Soviet Union. Many of the principles in the ANC's Freedom Charter (1955) express left-wing policy orientation. Further, the maintenance of the Tripartite Alliance ${ }^{1}$ into the modern era of South African politics, adequately exhibits that large portions of South African society haven't considered socialist 
thinking as inappropriate politics. In fact, the ANC in government still regards itself as 'a disciplined force of the left' with the leftist ideological gaze continuing to be a yardstick for legitimacy within the party and the alliance. We revert to this discussion later in the article.

At the turn of the 1990s, the world was shown minor liberal reforms in China and the collapse of the Soviet Union, as well as the demise of an ailing Global South Commintern. Shortly thereafter came the proclamation by Francis Fukuyama (1992) that liberalism ${ }^{2}$ had defeated all ideological opponents and could be deemed the undisputed champion of ideologies. However, sketching the outlines of the failure of orthodox communist orientations in the twentieth century does not serve as a valuable tool to assist this discussion. In fact, patterns of booms and busts in the late 1990s and 2000s have brought into question the idea of unregulated markets that have been propounded across the world. Times have changed too; socialism has changed and evolved. In evaluating why South Africa is unable to create an adequate socialist party that speaks to the working class (both lower and middle income), this article will offer examples of socialist reform that many South African politicians and policy-makers might have not considered. Beyond ideology, South Africa is largely considered a comfortably consolidated democracy (de Jager 2015; Landsberg and Graham 2017). Therefore it doesn't serve to exercise the discussion that South Africa could become an orthodox communist regime in the near future. At the stage in democratic consolidation that South Africa occupies now, regime reversal or democratic backsliding (see Bermeo 2016) seems unlikely.

Terreblanche (2002: 441) has previously proposed key interventions that could usher in a politico-economic system based on social capitalism and continental European-style social democracy. They include inclusive citizenship in which countries endeavour to achieve a more egalitarian society; 'sound social relations and restoring social justice'; a more interventionist orientation by a state with a competent and efficient bureaucracy; a strong civil society in a social democratic system; and a redefinition of welfare away from its embeddedness to 'growthmanship'. Some of the interventions reflect the emerging body of knowledge on developmental states as had been observed in East Asia and Latin American developmental eras (Leftwitch 2002; Chang 2002, 2003; Mkandawire 2001). 
To counter the tendency to write-off social democratic proclivities in the aftermath of the fall of communism, we seek to provide a snapshot of modern socialism in two ways. First, we outline countries in the world where socialist parties are governing (or have governed) with reasonably successful left-leaning policies. Secondly, we outline some of the socialist reforms that have become popular and welcomed in the twenty-first century. These provide a more suitable base to evaluate where the left has lost ground in South Africa and how a socialist orientated party could succeed in South Africa's multiparty system. It forms the important exercise of determining what lessons could be learnt from Latin America and Northern Europe.

As recent history shows, many popular narratives today are centred largely on how socialism can exist within plural representative systems. Whilst it is disputed that liberalism is the only viable ideology today, it is also largely accepted that electoral democracy is the most suitable regime model. The 2020 Economist Intelligence Unit's Democracy Index (EIU 2021) presently calculates that globally there are seventy-five full or flawed democracies, while worryingly a further thirty-five have been labelled as hybrid regimes due to a myriad of different democratic inconsistencies. Sadly, a further four countries have slipped into authoritarianism since 2018, that figure now totalling fifty-seven. Democracies, such as the flawed and hybrid regimes, may have fallen victim to the rise of populist authoritarianism in recent years, but the general trend is that, in many of these democracies, pluralism and elections are still considered the most suitable format of rule.

Most established or new socialist parties around the world tend to situate themselves within a multiparty electoral system and regularly contest elections. In various states, predominantly in Northern Europe, Central America and South America, socialist leaning parties also tend to be the ruling party or the leading party in coalition rule. Examples of states where ruling parties identify as socialist or left leaning are plentiful. Some popular examples in recent years include Uruguay, Sweden, Denmark, Iceland, Costa Rica, Mexico and Chile. Using The Economist's Democracy Index again, many of these aforementioned states are also considered some of the best consolidated democracies in the world (EIU 2021).

Today, the prevailing question about the prospects of socialism should no longer be 'Why do socialist regimes fail?' but rather 'If 
socialist elected regimes are ruling fairly successfully and democratically elsewhere in the world, why not in South Africa?' Socialist reform has obtained considerable popularity since the turn of the millennium. Social policy that seeks reform in the broader scope of distributive justice have also been implemented in countries as far ranging as Canada, France, Nicaragua, Venezuela and Brazil. These examples will be unpacked further in the following section. The argument could be made that socialist policy reform is applicable only to certain situational contexts. However, the existing literature shows that countries such as Brazil have appeared fairly similar in comparison to South Africa when discussing the criteria of socioeconomic stratification, unemployment, social services and levels of wealth and income inequality (Chitiga, Sekeyere and Tsoanamatsie 2014; Öniş 2016). Hence, the existence of a competitive socialist political party in South Africa should not appear as such an obscure concept.

Socialist parties or social policies are part and parcel of some of the most stable electoral multiparty democracies today. The following section will offer a brief glance at a few different cases where the democratic evolution of socialism over time has contributed positively to socio-economic development across the globe. We assess them with the view to gather lessons on the prospects of socialist politics and policies in South Africa.

\section{A Snapshot of Socialist-Aligned Parties and Policies in Democratic States}

To make the case for the feasibility of a South African socialist political party, it would be valuable to first discuss examples that explore some of the successes and limitations of socialist reformism $^{3}$ around the globe. This section will not focus specifically on one particular region, but would like to cover a diversity of examples ranging from Northern Europe, to Latin America, to North America.

Perhaps an old chestnut, but at this juncture it would be impossible to ignore social democracy in Northern Europe. South Africa and states of Northern Europe are both figuratively and literally polar-opposites in respect of historical circumstances, ethnic 
homogeneity, class stratification and inequality levels. However, this does not negate the possibility that lessons may be learnt from countries such as Sweden, Norway, Iceland, Finland and Denmark as a starting point, or for the purposes of benchmarking the discussion.

Scandinavian, or Northern European, states provide a valuable premise for benchmarking modern socialism in democratic states, as many of them feature very highly on democratic rating platforms. The Economist Intelligence Unit's Index (EIU 2021) places Norway, Iceland, Sweden, Denmark and Finland in the top ten most successfully functioning democracies in the world. All of these countries are either social democratic in rule or policy practice. Similarly, Norway, Iceland, Sweden, Denmark and Finland are all among the best ten performing countries regarding income inequality indicators, whereby income inequality is almost non-existent in most Northern European states (OECD 2017). In the Organisation for Economic Co-operation and Development's (OECD) Income Inequality Index, all of the aforementioned countries obtained between 0.2 and 0.3 on a scale where absolute equality is measured as ' 0 ' and absolute inequality is ' 1 '. The World Bank's (2019) GINI co-efficient indicators also show that all of the aforementioned countries fall within the top twenty most equal societies in the world. These statistics are meaningful under the perception that socio-economic progress in the twenty-first century could have more to do with alternative economic development indicators, instead of the neoliberal staple of rapid economic growth or gross domestic product (GDP) used in the previous two decades (Fioramonti 2017).

As the table at right suggests, the social democratic states of Northern Europe and Latin America do not only perform well in the more traditional prosperity indicators, but also in the more alternative sustainable development indicators too. In a world moving beyond the monotony of GDP growth, it is perhaps of increasing importance for states of the Global South to pay more attention to alternative indicators that speak to citizen happiness, social progress, environmentalism and socio-economic equality, while simultaneously safeguarding political and civil liberties.

There is further sufficient evidence to suggest that socialist-leaning policy has not only been beneficial in social democracies, but 


\begin{tabular}{lllll}
\hline $\begin{array}{l}\text { G7 of } \\
\text { sustainable } \\
\text { development }\end{array}$ & $\begin{array}{l}\text { G7 of social } \\
\text { progress }\end{array}$ & $\begin{array}{l}\text { G7 of } \\
\text { environmental } \\
\text { performance }\end{array}$ & $\begin{array}{l}\text { G7 of economic } \\
\text { prosperity }\end{array}$ & $\begin{array}{l}\text { G7 of } \\
\text { happiness }\end{array}$ \\
\hline Costa Rica & Norway & Finland & Norway & Denmark \\
Colombia & Switzerland & Iceland & Switzerland & Switzerland \\
Panama & Sweden & Sweden & Canada & Iceland \\
Ireland & Iceland & Slovenia & Sweden & Norway \\
South Korea & New Zealand & Spain & New Zealand & Finland \\
Chile & Finland & Portugal & Denmark & Canada \\
New Zealand & Canada & Estonia & Australia & Netherlands \\
\hline
\end{tabular}

Table adapted from Fioramonti (2017). Data was drawn from the Happy Planet Index (2012), Social Progress Index (2015), Yale Environmental Performance Index (2016), Legatum Prosperity Index (2015), World Happiness Report (2016).

also in countries that have been considered to be essentially liberal democratic in identity. Accordingly, it is significant to consider the rise of democratic socialism ${ }^{4}$ in the United States. Socialist-leaning policy, even in countries that do not have an incumbent socialist party in power, remain popular around the globe.

The United States (US) provides an intriguing discussion concerning the prospects of democratic socialism. The US became much more polarised when the country took a sharp conservative turn with the election of Trump's Republican administration in 2016. But since then, left-leaning candidacy in the Democratic Party has become increasingly fashionable in America (Day 2018). Bernie Sanders, an admitted democratic socialist, has divided opinion in the Democratic Party since the previous Democratic National Convention in July 2016. He was narrowly defeated by the more moderate Hillary Clinton by a margin of 54 per cent to 46 per cent (Hayden 2016). At the time, Democrats made the incorrect assumption that they would be able to win over enough anti-Trump Republicans by electing the more moderate Clinton to the Democrat ticket instead of Sanders.

They would similarly deny Bernie Sanders the Democrat ticket for the 2020 national election, favouring the now President Joseph Biden. Biden defeating Trump in the 2020 election was inevitable due to the latter's abysmal handling of the American presidency from 2016 to 2020. It also showed that the country desired a more progressive regime after Trump's deeply conservative approach. 
While moderate in comparison to the social democrat views expressed by the Sanders camp in the Democrat party, the idea is that America may be again leaning towards progressive politics of affordable healthcare, welfare and progressive taxation (Roberts 2019). The hope for many Americans is that the left-wing sect of the Democrat party will be able to find common ground with Biden's moderate camp.

Sanders' campaigns in 2016 and 2020 by democratic socialist standards wasn't exactly politically radical, but it certainly stretched the Overton window in the United States to the limit of what was politically acceptable from the left in 2016 and 2020. The previous section discussed the latent fear of communism, especially in the United States: Sanders knew he would have to navigate quite a narrow ideological tightrope. He ran on the central mandates to provide free, accessible and equal healthcare for all Americans, abolition of exorbitant college fees and student debt, and progressive taxation for those that earn more than $\$ 250,000$ annually.

While the US might not have chosen socialist reform in 2016, nor during the 2020 election when moderate left-leaning Biden was elected, there is still a growing sentiment that democratic socialism has firmly entered the conversation in political dialogue among civil society. Candidates such as Sanders and Ocasio-Cortez have gathered considerable support from young Americans (Day 2018). When Sanders came to national prominence, the idea of abolishing private healthcare was covered by the American media as communist hysteria, but in 2019 it fast become a central policy orientation of the Democratic Party (Draper 2019). One of the key surprises is how much socialist-leaning policy reform resonates with young people.

Ocasio-Cortez has strongly advocated for a Green New Deal, whereby environmental sustainability and renewable energy may become the next big ideological frontiers in the United States. Essentially the Green New Deal is built on a platform of green socialism. Chang and Lee (2019) contends that modern global capitalism is further exacerbating inequality and various social contradictions. They argue that the fallout of a decline of neoliberalism in the last decade has produced three new camps: inclusive capitalism; militarised accumulation; and Green New Deal narratives. OcasioCortez is not alone in these endeavours. She is leading figure in 'The Squad', which is a group of young people of colour in Congress that 
represent the Democrat party. The group is made up of Alexandria Ocasio-Cortez, Ilhan Omar, Ayanna Pressley, Rashida Tlaib, Jamaal Bowman and Cori Bush. These Congresswomen and Congressmen have been known to advocate for socialist reform and better ecological stewardship. The response (especially on social media) from young America shows that they are quite taken with democratic socialism.

Inclusive capitalism and green socialism have garnered considerable attention in democratic countries, whilst alarmingly a few democracies have also moved towards authoritarianism. The latter is not relevant to this discussion, as we have outlined earlier that this paper seeks to deal only with consolidated multiparty democracies. Ocasio-Cortez has also managed to mobilise a considerable portion of American youth both in public forums and on social media (Roberts 2019). The evolving nature of socialism globally has become impossible to ignore; and thus further imbues the overarching question, 'What prohibits the successful development of a socialist leaning parties in South Africa?'

Possibly the closest region in similarity of political, social and economic circumstances to South Africa may be Latin America. Countries such as Brazil, Venezuela, Nicaragua, Ecuador or Uruguay offer seemingly appropriate examples. The results of the Pink Tide ${ }^{5}$ have not been straight forward successes, and it is valuable to speak to some of the failures for the sake of parity. The two deepest contentions are the reversal back to conservative politics in countries such as Brazil, Argentina or Chile, and the decline of Venezuela into authoritarianism since Nicolás Maduro's regime replaced the deceased Hugo Chávez. Ellner (2019) suggests that a few conditions, some internal and others external have contributed to a recent slump in Latin American socialism in the aforementioned states,

... Analysts on the right attributed the political and economic woes faced by progressive governments to economic interventionism, a model they considered to be tantamount to socialism. These attacks from critics at the international level reflected what was happening politically at the national level. The phenomenon known as the pink tide, consisting of a rapid succession of electoral triumphs of leftists and centre-leftist presidential candidates at the outset of the century, has heightened internal tension and set off intense political and social polarization in each of the nations. 
Firstly, ideological polarisation was a key issue in many of these states. As leftist regimes took office, it triggered the remobilisation of conservative entities, which would eventually bring politicians like Bolsonaro to power in Brazil in 2019. Secondly, the fallout of the 2008 economic crisis drastically affected oil prices, leading to the decline of the socialist regime in Venezuela. Finally, external opinion and diplomacy was incredibly divisive. Many of the Latin American leftist regimes were portrayed as distinctly anti-American which created considerable diplomatic pressure (Ellner 2019). The United States in turn launched a diplomatic offensive similar to its anti-communist Cold War policy in Latin America, as it supported opposition parties in many of the Pink Tide countries and also attempted to apply economic sanctions, most notably against Venezuela.

Aside from these challenges, there is still much to be said about the positive contributions of the Pink Tide to socio-economic redistribution and development in Latin America since the dawn of the new millennium. In Brazil for instance, under the Lula and Rousseff Workers' Party administrations, considerable strides were made in social policy reform (Rojas 2017). Luiz Inácio Lula da Silva successfully presided over an ' . . extraordinary period of economic growth and reduction of inequality as innovative cash transfer schemes took tens of millions out of poverty' (Phillips 2019). The Workers' Party-led regime in Brazil, however, suffered a heavy decline in support after Lula was implicated in accusations of corruption and patron-clientism in what is popularly known as Operation Car Wash. Lula was later arrested and jailed for involvement in the scandal that saw extensive money laundering and collusion with Brazil's biggest oil company, Petrobas. Phillips (2019) later wrote in The Guardian that Lula had since been freed from prison after The Intercept's investigative journalist, Glenn Greenwald, leaked that the judicial figure presiding over the case against Lula was a known associate of his right-wing opponent, Jair Bolsonaro, who is now the current president of Brazil. There is reason to believe that the decline in support for Brazil's Workers' Party may have been rigged in order to bring Bolsonaro to power. At the time of writing this is still a developing story.

The Chavez period of Venezuelan politics also provides significant lessons for nations of the Global South. Before its eventual 
decline under Maduro, Venezuela was globally admired for much of the twenty-first century as a bastion of state-intervention for redistribution, upgrading education infrastructure, anti-imperialism and incremental changes in the socio-economic lifestyles of Venezuelans. Bolivarianism (as Chavez's movement has been termed), was successful in diffusing militancy and authoritarian language which had previously been a strong feature of Latin American politics (de la Torre 2017). His policies resonated well with broader Venezuelan society, as the people felt they would not have to relinquish any of their political and civil liberties for more equitable socio-economic development. Chavez successfully achieved this by using electoral and constitutional mechanisms to traverse the tightrope of state, private, and communal forms of capital and property, instead of seizing the means of production in a Marxist-Leninist fashion.

Furthermore, redistributive governance and social policy reform have been very successful in countries such as Uruguay, Bolivia, Costa Rica and Nicaragua in the twenty-first century. Even though there is the distinction that some of the Pink Tide nations were more moderate and others were more radically left-wing, in almost all of them discernible strides in social policy and redistributive justice were made. In Nicaragua, the state undertook extensive public-funded literacy programmes. Bolivia was initially able to prevent the predatory privatisation of the county's water supply when Morales came to power, whilst also implementing food security programmes. Ellner (2019) articulates further that in states such as Nicaragua, Bolivia, Ecuador, Venezuela and Uruguay public participation, non-elite decision-making and representation of marginalised groups were also meticulously implemented. Lastly, in Uruguay increased non-elite participation and decision-making led to advances in the areas of education, wage increases, social security, and healthcare (Bentancur \& Busquets cited in Ellner 2019).

A snapshot of some of the progressive social policy reforms under socialist party rule in Latin America, speaks unto many of the same rights and socio-economic issues presently found in South Africa. Bearing in mind similar conditions in education and healthcare provision, wage inequality, social security, food security and exclusion of marginalised groups, it further bolsters the question surrounding the inability of South Africa to produce a viable 
socialist or workers' party that could assist in alleviating some of the same socio-economic issues that were reduced in states such as Brazil, Uruguay, Venezuela and Costa Rica.

In sum, there are several positive lessons that may be taken from this enquiry into socialist politics around the globe, especially from some of the Latin American cases covered in this first portion of the article. It is certainly apparent that a country such as South Africa would benefit from an affordable healthcare act or national health insurance, increased welfare and redistribution, progressive taxation of the wealthiest portions of society, as well as more humane and protective labour regulations and wages. These types of advances need not be made in complete opposition to the standard objectives of acquiring foreign direct investment and diminishing barriers to trade. However, as Global South countries develop in the twentyfirst century, there is certainly more scope for a balanced approach to the ideological framing of the state. South Africa could certainly benefit from increased socialist policy orientation.

\section{The History of Socialist Institution Building in South Africa}

This section outlines the history of socialist institution building in South Africa to provide the necessary background context for the current debate about prospects for a social democratic path. Two broad historical developments are necessary for consideration in this respect. First, precolonial cultures of collectivism among Africans and the legacy of the political economic responses to the process of transforming the mode of production in the country to become more capitalist in its orientation. The legacy of precolonial African cultures into modern-day politics in South Africa is discussed further below in the section discussing prospects for a decolonial socialist approach. A discussion of the immediate response of oppressed people to increasing oppression necessitated by capitalist accumulation follows immediately.

After the loss of their land and means of subsistence through wars of dispossession in various territories of modern-day South Africa, Africans begin to focus their struggles gradually on creating an inclusive political economy in South Africa. The African 
intelligentsia begin to envision an inclusive political economic society that is conducive for all to succeed. From the 1890 s until the 1920 s there was a significant increase in industrial action among workers whose purposes were to increase the share of workers in the national income. The formation of the Communist Party of South Africa in 1927 and its focus on organising black workers in later years ensured workers' issues remained a focal point of struggle for liberation even though the organisation had started mainly from the white community.

Van Niekerk (2017) traces the origins of social democratic ideas in the ANC as a political movement to the early 1940s under the leadership of Dr Alfred B. Xuma when the liberation movement crafted documents titled African Claims. He argues that the ANC followed the example set in the Atlantic Declaration which sought to expand democracy around the world and ensure inclusive welfare of a population through provision of public goods (2017:44). Through an analysis of the speeches of Xuma and Albert Luthuli, van Niekerk states that the two leaders were among some of the critical social democratic voices within the ANC. What attests to this seeming advancement of social democratic ideals for van Niekerk are both the messages in African Claims, the Freedom Charter and the political speeches of the two leaders. Although the policy thinking within the ANC and the broader liberation movement did not unfold in a unidirectional manner, it remained contested throughout the history of the party.

In the democratic period, the thinking about and attempts to create a left leaning political economy in South Africa shifted from a feeling that the National Democratic Revolution would result in a communist state to one of social democracy in line with the shift we previously highlighted. Significant contributions to South African Communist Party (SACP) debates in the early 1990s focused on the shifts taking place around the world and their implications for the content of the South African approach to building a social democracy (Slovo 1990; Veit 1992). While NUMSA still cites its aspirations for a Marxist-Leninist version of communism, the dominant thinking within the Tripartite Alliance is one of a social democratic approach to managing the South African political economy. In fact, the rhetoric of the ANC shows a party which is 'disciplined toward the left' and not a communist party per se (African National 
Congress 2018:13). Its mandate as derived from the National Democratic Revolution is limited to creating 'a democracy with a social content' with some key traits of a social democracy. This is distinguished from the mandate of the SACP and the Congress of South African Trade Unions (COSATU), which it regards as more traditionally communist entities (ANC 2018:13).

The extent to which the ANC could be regarded as a leftist party within the Tripartite Alliance has been a source of significant contestation. Since technocrats within the governing party replaced the more socially orientated Redistribution and Development Programme with Growth, Employment, and Redistribution in 1996 without much consultation within the alliance, the SACP and COSATU criticised the ANC for regressing toward neoliberalism. The dominant struggle between the ANC and its alliance partners centred on the ideological orientation of the state. The shift in macroeconomic policy was labelled as 'the class project of 1996' by the left. In turn, then President Thabo Mbeki labelled those who were critical of the ideological stance of his regime as ultra-leftists. What this contestation meant was that the political home for leftist political expression in the country became severely diminished.

The locus of power for not just advancing socialist orientated policy in South Africa, but also thoroughgoing political economic change, has tended mainly to be within the federations of worker unions (Lever 1981 cited in Allais 1985:7) and civic associations. This is of course if the objective history is to be taken into account, among other nuances. The 1913 strikes in the mining sector served as a defining moment in the history of the leftist struggle in the country (Marais 2011). In fact, COSATU regarded its strategic intent as having always been focused on not just a greater share of income by workers but also broader social struggles, including liberation and socialism (COSATU 1997).

The SACP and various black unions formed alliances with the ANC. Throughout the struggle for liberation and the democratic period, leaders of especially black labour unions played active roles in the struggle for liberation with direct affiliation or membership in the ANC and the SACP. This was both a matter of deliberate strategy and, at times, emergent alliances at a tactical level. The symbiosis between national liberation politics and the struggles of workers for a greater share of the national income and better living conditions saw 
many of the leaders of trade unions suffer the brunt of the security establishment under apartheid. It led to the ultimate banning of the South African Congress of Trade Unions' leaders along with the liberation movements and the communist party among others (Friedman 1987). Black unionism would regain its strength in the $1980 \mathrm{~s}$ following the 1979 reforms that made it possible for black workers to once again organise themselves legally in the country (Allais 1985).

The African National Congress underwent a significant transition in its perceptions about the role of the state in the economy in the period leading to its ascent to power in 1994. Terreblanche (2002), and Gumede (2005) conclude that the ANC did not have an established economic plan when it entered the transition for a democratic South Africa and, as such, was convinced by a dominant capitalist class in the country to accept neoliberalism. This may have signalled the beginning of the end of vibrant socialist politics in the country.

Since the advent of democracy, political parties such as the Congress of the People (COPE) have flirted with social democratic policy orientation, but have since abandoned it somewhat by aligning itself with recognised conservative entities such as AfriForum (Ndaba 2018). The ideologically inconsistent and often boastfully ethnic nationalist Economic Freedom Fighters (EFF) have also espoused some Marxist-Leninist economic policies, which notably are built on old scientific socialist platforms of nationalisation and state-centralised collectivisation.

However, there is still no imbedded socialist workers' party in South Africa, especially one that lends itself toward social democracy or alternatively democratic socialism. Therefore, it was an important moment when NUMSA resolved to form one in 2013. The union did not follow through in a convincing way in implementing that resolution though. Instead, it took missing a national election and local government elections in 2014 and 2016 respectively in order to get the party act on its 2013 resolution. The following section offers a critical review of such an approach.

\section{NUMSA's Socialist Party Experiment in South Africa}

The National Union of Metal Workers of South Africa has thus far had two failed attempts at starting a socialist party in South 
Africa. At its conference in 2013, the organisation resolved to form a mass-democratic social movement in the style of the erstwhile United Democratic Front and a workers' party that could contest elections. The former would be a non-ideologically aligned movement that would mobilise social forces towards the goal of holding government more accountable, while the latter would be a political party that would seek to wrest control of the levers of state power in order to advance a socialist political system along the lines of Marxist-Leninism. The six years that followed that resolution have been nothing short of utter confusion for the union. First, on the eve of the local government elections in 2016, organisations affiliated to a so-called United Front registered and contested the elections. As Mtimka (2016) outlines, until July that year, NUMSA was still confused about the role of the United Front in the resolution to form a workers' party and as such there was virtually no support for the United Front or it's 'affiliates' on the campaign trail leading to the elections. Only on a few occasions did the secretary general, Irvin Jim, campaign with the respective leaders of the 'civic associations'. The party produced a poor showing but managed to secure a seat in Nelson Mandela Bay, Senqu Municipality in Sterkspruit in the Eastern Cape, and a single seat and mayoral position in Bitou Municipality in the Western Cape.

This is an important interlude in the period between the resolution in 2013 and the launch of the SRWP in 2019 for a number of reasons. First, there is a sense in which the United Front experiment showed a degree of confusion about the resolution and how it would be implemented. Although the front was touted as a non-partisan mass-based organisation which would lead a broad range of social forces in fighting against social ills, it became a political party in practice. There was the United Front of the Eastern Cape that contested elections in Nelson Mandela Bay and Bitou in the Western Cape and a Civil Movement in Senqu municipality as stated above. Internal party documents showed a degree of confusion up to the eve of the 2016 local government elections regarding whether the United Front was the actual workers' party or the association of civics as stated in the original resolution.

The clearest indication based on reviewed internal documents was that some within NUMSA did indeed see the United Front experiment as the pathway to a workers' party, if not the workers' 
party itself. Indeed a national coordinating structure was formed seemingly to drive the national campaign but without compelling support from the leadership. The inner core of the leadership were not yet persuaded that this was the case or were divided. This explains why the support of NUMSA to the United Front and its affiliates was insignificant when it comes to running an effective election campaign.

As if NUMSA had not learned from its mistakes in the United Front experiment, the party repeated all the mistakes it had made therein when it ultimately registered the Socialist Revolutionary Workers' Party to contest the 2019 national general elections. As stated above, two elections - the national elections in 2014 and the local elections in 2016 - had passed since the resolution was made in 2013. However, the union only registered the Socialist Revolutionary Workers' Party (SRWP) hardly two months before the 2019 elections, delayed implementing a high visibility campaign until very late, and had the dubious move of charging its secretary general, Irvin Jim with the responsibility to lead the party. Mtimka (2016) outlines in detail how the internal issues within NUMSA negatively affected the performance of the United Front and, roughly, the same issues affected the performance of the SRWP.

The SRWP performed dismally in the 2019 national general elections, much to the dismay of its leader who regarded the results as a joke and possibly manipulated. The party obtained 24,439 of the national votes, translating to a share of just 0.14 per cent in the last national general election and missed securing even one seat in the sixth parliament despite the fanfare with which it was launched.

In a country where liberation politics until the early 1990s had been firmly built on pro-worker socialism, these election results for a fully fledged workers' party (independent of the Tripartite Alliance) make for abysmal reading. However, the failure of the SRWP experiment is perhaps best explained by factors beyond its own making. Among other things, left politics in South Africa have remained within the Tripartite Alliance of the ANC, COSATU, and the SACP. The rise of the EFF has meant that a significant number of voters who seek a leftist alternative to the ANC have a more radical party to campaign for their issues and a wide range of smaller organisations have sought to challenge the dominance of the ANC. The next section covers these issues in more detail. 
Table 1: Provincial breakdown of votes received by the SRWP in 2019

\begin{tabular}{lcc}
\hline Province & Number of votes & Share of the vote \\
\hline Eastern Cape & 4448 & $0.22 \%$ \\
Gauteng & 5465 & $0.13 \%$ \\
Western Cape & 3026 & $0.15 \%$ \\
Free State & 1567 & $0.18 \%$ \\
KwaZulu Natal & 4222 & $0.12 \%$ \\
Limpopo & 1392 & $0.10 \%$ \\
Mpumalanga & 1814 & $0.15 \%$ \\
North West & 1884 & $0.20 \%$ \\
Northern Cape & 542 & $0.14 \%$ \\
\hline
\end{tabular}

Source: Adapted from IEC 2019.

Table 2: Most successful results for the SRWP in major municipalities

\begin{tabular}{lrc}
\hline Municipality & Number of votes & Share of the vote \\
\hline Nelson Mandela Bay & 2,015 & $0.51 \%$ \\
Buffalo City & 613 & $0.23 \%$ \\
City of Johannesburg & 1,620 & $0.11 \%$ \\
Ekuruleni & 2,158 & $0.19 \%$ \\
Tshwane & 809 & $0.08 \%$ \\
eThekwini & 2,059 & $0.15 \%$ \\
City of Cape Town & 1,273 & $0.09 \%$ \\
\hline
\end{tabular}

Source: Adapted from IEC 2019.

\section{Explanatory Factors beyond SRWP}

A factor worth consideration when analysing the prospects of any left-leaning political party outside of the Tripartite Alliance in South Africa in the post-post-apartheid period is the general role the alliance plays in creating an impression of representation of those who prefer left-leaning policy, especially workers. The alliance leadership has felt that the leftist project was better represented within the alliance led by the ANC than outside of it. Leading to the Polokwane conference of the ANC, it was felt that defeating former President Mbeki would defeat the class project of 1996 and create space for more progressive policy in the form of a developmental state, notwithstanding his own commitment thereto as seen in the Accelerated and Shared Growth Initiative for South Africa. When Zuma failed to take more decisively left policies, the alliance felt that he could have 
a 'Lula moment" ${ }^{6}$ in his second term and radically transform policy to favour progressive outcomes. In the lead up to the National Recreation Center conference, it was felt that Cyril Ramaphosa should be given a chance to stymie a tide of corruption and deliver much needed 'new dawn' that would benefit workers.

This positioning of the ANC and usage of ANC succession politics by the trade union movement and the SACP as a key path towards a pro-worker policy orientation has been the basis upon which workers have been led to continue to vote for the ANC. To be fair to the leftist alliance of the governing party, they have made calls consistently for the transformation of alliance relations to be geared more towards achieving outcomes deemed appropriate for the interests of the working class. As a result of the close influence of the trade unions and the SACP, the ANC has had its significant share of socialist policy implementation.

\section{Towards a Decolonised Discussion on Socialist Politics?}

Any analysis of socialism and socialist thought in South Africa has to begin with an interpretation of the precolonial culture of the African people in the country as has been observed from its surviving practices and as implied in various indigenous languages. Based on the apparent similarities among many African population groups, African culture often appears to have a strong communitarian orientation. Writing about Oliver Reginald Tambo, Callinicos (2011:25) describes the precolonial cultures 'collective social structures and a world view, despite occasional clash of interests between one clan and another, of the practical value of warm relationships and a deep respect for a shared humanity'.

The values of Ubuntu that are common especially among Southern African indigenous groups confirm such an inference (Khoza 2005). Furthermore, the following isiXhosa proverbs emphasise this orientation.

- Akukho qili linokuzikhotha emhlana, which means there is no 'qili' (a certain animal) that can leak (sic) its own back;

- isandla sihlamba esinye, meaning one hand washes the other; and 
- isizwe sifa ngomntu omnye, which means a nation can perish on account of one person.

These proverbs point to the cherished values of communitarianism among Nguni-speaking and arguably many other African cultures. They demonstrate that individuals need to nurture relationships in society and they must be bound by values of fair mutual contribution to communal wellbeing in order to thrive continuously. In fact, the third shows the individual is so much a part of the community that their conduct may even determine the fate of an entire nation, hence there is a strong commitment to ensuring that individual liberties are limited by the harm principle with such harm defined broader than just 'the next person'. There are many examples that underscore the potential consequences of individual behaviour far beyond the individual and their family. It still is common in many rural areas to have an intervillage conflict sparked by a conflict between just two people. The battle of Amalinda in history was sparked by a domestic conflict over Thuthula between chief Ngqika and his regent chief uncle Ndlambe. When AbaThembu king Ngangelizwe beat his wife Novili, the daughter of AmaXhosa king, Sarhili, the latter waged war against the AbaThembu nation in the mid 1800s.

On production and production relations, what can be deduced from the proverbs are fascinating concepts. Among these is the idea that it is okay for one to provide their labour and resources in order for another to increase their yield and production. It is captured in the proverb that 'intaka yakha ngoboya benye', meaning a bird builds its nest using another's. For example, amaXhosa embraced the concept of Ilima in terms of which many members of the community would offer their labour to one another during the planting (Peirres 2003; Bundy 1979). Ploughing, and harvesting seasons without expecting payment for their time. All that would be offered is one form of entertainment or another (Peirres 2003; Bundy 1979). During harvest time, the harvest would be shared with others in the community but there was not collective claim to a private garden in a transactional fashion.

To counterbalance against destructive competitive rivalry and selfishness, which are often considered as traits of late capitalism, an individual or family that shows generosity towards others is held 
in higher regard than one that hogs and flaunts its wealth. In other words, while relative competitiveness is allowed to the extent that those who have good results from their hard work are commended, the outcomes would be frowned upon if they reflected crass materialism with no regard of the greater wellbeing of others and the community. To that end, the derogatory term uzityele (the one who eats alone) is used to refer to any person whose disposition is towards self-interest and individualism. Another term that shows the community's disdain for ultra-individualism is uhlohlesakhe. It literally means 'The one who stuffs his own [stomach]'. Both terms are used in derogatory fashion, underscoring the community's displeasure towards the self-interested and individualistic.

As is the case with many other aspects of post-colonial life, African leaders and communities have largely failed to ensure that their underlying values are translated into institutions and systems that draw boldly from the rich heritage of precolonial culture. As the adage goes, capitalism permeates every aspect of socio-politicoeconomic reality. Furthermore, the inferiority complex arising from mental enslavement under segregationist policies has precluded an inside out approach to building institutions in South Africa and a preference has been shown for foreign concepts that have been imposed on the continent. Where some breakthroughs have been made with respect to bringing values such as Ubuntu into the public domain, it remains limited only to philosophy with no attempt to draw practical applications in institution building or influencing how systems operate. But if these precolonial communal traits can show us anything, it is that South Africans have had an intercepted but strong historical association with overall citizen happiness, social progress, environmentalism, socio-economic equality, social security, equal work, redistribution, healthcare and education. As the earlier sections have shown, these traits are somewhat similarly valued in the social democracies of Latin America and Northern Europe.

One of the key traits about African knowledge systems is the focus on values being integrated on all that is being done and changing institutions from a values-driven point of view rather than building institutions which have the sole responsibility of enforcing those views. Life and institutions are not compartmentalised and theorised devoid of the social context found in many African 
communities, hence there was little disjuncture between institutions of learning, production, and economy and policy. Within the confines of family and community knowledge was passed, production undertaken, and relations enforced with the economy and polity. Perhaps the challenges with building political institutions, whose exclusive mandate is to carry out socialism, underscore the fact that socialism or communitarianism ought to be in the hearts and minds of every member of society so that institutions can be influenced to embody the cherished values from the inside out rather than from outside in.

From this perspective, there should be no pressure to build a political party. The values of caring, distributing opportunities and resources more equitably, and commitment to hard work that takes society forwards can be embodied by a coalition of social forces beyond parties. Socialist thinking and political organisation in South Africa has enjoyed a leveraged or augmented position rather than being embodied in one political organisation. The left has been able to enforce key incremental concessions from the political economic system. The milestones from this leveraged position have been, among other accomplishments:

- South Africa's progressive taxation system which has been regarded as one of the best examples of redistribution across the world. South Africa scores highest in Africa for 'commitment to change inequality', thirty-one globally, and third in its 'tax score' and pensions paid to senior citizens reduce inequality by 22 per cent (Oxfam 2019:15).

- The highly protective regulatory framework since the mid1990s.

- The increase in the number of the lower-middle class since the early 2000s.

- The increased number of sector specific minimum wages as well as the implementation of a national minimum wage.

The share of the national income for the working class in real rather than nominal terms remains a challenge but the country is not where it was prior to the 1970s when the cheap labour system ended as the pillar of South Africa's racial capitalist system (Terreblanche 2002). One should bear in mind that the continuing inequality, high rates 
of unemployment, and poverty reflects what Terreblanche (2002) has regarded as the response of South African Capital to the accumulation crisis following the decline in the role of cheap labour as a key feature of the politico-economic system of the country. South African Capital introduced capital-intensive production methods, industrial consolidation through mergers and acquisitions, as well as Anglo-Americanisation (Terreblanche 2002) in order to counter the effects of changing domestic accumulation dynamics. For this reason, our contribution to the debate is that South Africa ought not only to look at Northern Europe or Latin America, as Terreblanche proposes, for a socialist democratic regulation of capitalism, but also for a more decolonised political economy. These conversations tie in firmly with the democratic atmosphere's continued grapple with socialist politics and political reform. It augers further for the necessity of a thriving left-wing in South African politics.

\section{Conclusion}

It was not the ambition of this article to prescribe that South Africa be governed by an unapologetically socialist political party. While certain socialist parties and policy orientations have been successful in both the developed world and the Global South that does not necessarily indicate that a socialist political party in South Africa would be able to alleviate all of the socio-economic ailments in the country.

However, what we have endeavoured to do is, firstly, show that socialist parties and policy orientations have been phenomenally successful in many countries in the twenty-first century; and that, secondly, South Africa provides a very suitable incubator for socialist political parties and socialist policy reform. What remains a conundrum is why there hasn't been an electorally successful socialist workers' party to speak of since the inception of democracy in South Africa. While the Congress of the People flirted with social democracy when the party was created; and the ideologically inconsistent and ethnic nationalist Economic Freedom Fighters do espouse some socialist economic policies, there is still no established socialist workers' party in South Africa. Perhaps due to a lack of political will and drive, Irvin Jim's Socialist Revolutionary 
Workers' Party has so far failed to capture the hearts and minds of left-minded South Africans, who themselves have continued to become apathetic towards electoral politics in recent years.

South African electoral politics is sorely lacking a principled socialist-leaning political entity. We say this, not because of specific ideological proclivities, but rather because it is essential for consolidated democratic parties in the modern era to provide voters with a rich and varying degree of different ideological platforms to support. South Africa does not have a shortage of political parties, but what it does lack is an enticing ideological menu for voters.

Further, a decolonised approach couched in precolonial history also implores us to appreciate the socialist lifestyles Africans experienced before colonisation. Furthermore, South African liberation politics was forged in left-wing political and economic thinking. However, due to the limited offerings of socialism beyond the Tripartite Alliance, and the failure to launch of other socialist political parties, the prospects for socialist politics or policy reform remain weak. As Latin America did in 1999, we could comfortably argue that many South Africans yearn for a socialist-leaning vehicle to support, but we remain bemused as to why no political party has yet stepped up to deliver one. As we move into another election period, with the impending 2021 local government elections on the horizon, we will again be pressed to ask the question 'Is there space for democratic socialism and socialist political parties in the South African political landscape?'

Giovanni Poggi is a lecturer in the Department of History and Political Studies at Nelson Mandela University. His foundation was a BA in international studies from Stellenbosch, but he migrated research interests as a postgraduate towards philosophy, ideology, identity and political economy. His current research efforts are still centred more broadly on the alleviation of political and socioeconomic exclusion on the African continent. His present doctoral thesis is focused on researching models of developmental political economy for sustainable development in sub-Saharan Africa. He teaches political philosophy and ideology, African politics and political economy at undergraduate and postgraduate levels. E-mail: Giovanni.Poggi@mandela.ac.za 
Ongama Mtimka lectures democratisation and state transformation, South African politics, and international political economy at Nelson Mandela University in Port Elizabeth, South Africa. He comments regularly on South African politics as a political analyst on national and international media. His key research interests are in party politics, political economy, and development. Mtimka holds a Bachelor of Arts (journalism) from Rhodes University and a Masters in South African politics and political economy from Nelson Mandela University, where he is also completing his $\mathrm{PhD}$. He has extensive working experience in industrial and community development, as well as local government. He is the Treasurer of the South African Association of Political Studies. E-mail: Ongama.Mtimka@mandela.ac.za

\section{Notes}

1. The Tripartite Alliance comprises the African National Congress, the South African Communist Party and the Congress of South African Trade Unions.

2. 'Liberalism' in this article refers to centrist or even libertarian politics. Politics of the northern hemisphere often refers to liberal or 'democrat' politics as left-leaning or welfarist. To avoid confusion, this article will instead discuss liberal politics as 'centrist' to fit the South African political lexicon.

3. Reformism in this context refers to the view that gradual changes provided by socialism through existing institutions can eventually lead to fundamental changes in a society's political and economic systems. Reformism as a political position for social change emerged from opposition to revolutionary socialism. Whilst promoting socialist reforms, it does not simultaneously advocate for the overthrow of a [democratic] regime (Gorz 1987).

4. This article makes use of both social democracy and democratic socialism. One should, however, highlight the distinction between these two ideological positions. Social democracy enjoys the benefits of increased regulation and taxation of the private sector, and ultimately believes that capitalism can be shaped to provide equitable distributive justice and welfare. Democratic socialists on the other hand, while following a similar method, believe that increased regulation of capitalism over time should lead to its eventual redundancy and replacement by a modern form of collective ownership (see Baradat and Phillips 2017; DSA 2019 ).

5. The Pink Tide refers to the trend towards the growth in support for socialist parties in many Latin American countries since Hugo Chávez came to power in Venezuela in 1999. Since then, Argentina, Bolivia, Brazil, Chile, The Dominican Republic, Ecuador, El Salvador, Honduras, Mexico, Nicaragua, Paraguay, Peru and Uruguay have or have had extended periods of democratically elected socialist rule (Ellner 2019).

6. The Lula moment refers to the coming to power of Luiz Inácio Lula da Silva in Brazil, where he was president from 2003 to 2011 . In this period, Lula was also the leader of Brazil's Partido dos Trabalhadores (Workers' Party). 


\section{References}

African National Congress. 1955. Freedom Charter. Adopted at the Congress of the People. Kliptown (25-26 June 1955).

African National Congress. 2018. 'A brief history of the ANC', www.anc1912. org.za/brief-history-anc (accessed 23 April 2021).

Allais, C. 1985. 'The socio-political role of emergent trade unions: Perceptions of trade union leaders'. Research Finding MN-113. Pretoria: Human Sciences Research Council.

Baradat, L. and J. Phillips. 2017. Political Ideologies: Their Origins and Impact. New York: Routledge.

Bermeo, N. 2016. 'On Democratic Backsliding', Journal of Democracy 27 (1): 5-19.

Bundy, C. 1979. The Rise and Fall of the South African Peasantry. Cape Town \& Johannesburg: David Phillip.

Callinicos, L. 2011. Oliver Tambo: Beyond the Ngele Mountains. Cape Town: David Phillip.

Chang, H.J. 2002. Kicking Away the Ladder: Development Strategy in Historical Perspective. London: Anthem Press.

Chang, H. J. 2003. Rethinking Developmental Economics. London: Anthem Press.

Chitiga, M., E. Sekeyere and N. Tsoanamatsie. 2014. 'Income inequality and limitations of the GINI index: the case of South Africa', HSRC, www. hsrc.ac.za/en/review/hsrc-review-november-2014/limitations-of-gini-index (accessed 27 July 2019).

Chang, A. and D. Lee. 2019. 'What's actually in the Green New Deal', Vox, www.vox.com/videos/2019/6/12/18653754/green-new-deal-video (accessed 12 April 2021).

Day, M. 2018. 'Democratic socialism, explained by a democratic socialist', Vox www.vox.com/first-person/2018/8/1/17637028/bernie-sanders-alexandriaocasio-cortez-cynthia-nixon-democratic-socialism-jacobin-dsa (accessed 5 August 2019).

de Jager, N. 2015. 'Procedural Democracy in South Africa', in N. de Jager (ed), South African Politics: An Introduction. Cape Town: Oxford.

de la Torre, C. 2017. 'Hugo Chávez and the diffusion of Bolivarianism', Democratization 24 (7): 1271-1288.

Draper, R. 2019. 'How 'Medicare for All' Went Mainstream', New York Times, www.nytimes.com/2019/08/27/magazine/medicare-for-alldemocrats.html?rref=collection percent2Ftimestopic percent2FDemocratic percent20National percent20Convention (accessed 30 August 2019).

Drier, P. 2019. 'How Democrats Should Respond to the GOP's Red-Baiting', The Nation, www.thenation.com/article/gop-red-baiting-2020/ (accessed 3 July 2019). 
DSA USA. 2019. 'What is Democratic Socialism', Democratic Socialists of America, www.dsausa.org/about-us/what-is-democratic-socialism/ (accessed 15 August 2019).

Ellner, S. 2019. 'Pink Tide Governments: Pragmatic and Populist Responses to Challenges from the Right', Latin American Perspectives 46 (1): 4-22.

Fioramonti, L. 2017. The World After GDP. Cambridge: Polity Press.

Friedman, S. 1987. Building Tomorrow Today: African Workers in Trade Unions, 1970-1984. Johannesburg: Raven Press.

Fukuyama, F. 1992. The End of History and the Last Man. New York: Free Press.

Geoghegan, V. and R. Wilford. 2014. Political Ideologies: An Introduction. New York: Routledge.

Gorz, A. 1987. Theories of the Labor Movement. Detroit: Wayne State University Press.

Gumede, W.M. 2005. Thabo Mbeki and the Battle for the Soul of the ANC. Cape Town: Zebra Press.

Hayden, M. 2016. 'Hillary Clinton Makes History as Democratic Nominee', ABC News, https://abcnews.go.com/Politics/democrats-begin-conventionroll-call-amid-divisions-ranks/story?id=40898573 (accessed 15 August 2019).

Landsberg, C. and S. Graham. 2017. Government and Politics in South Africa: Coming of Age. Johannesburg: Van Schaik.

Leftwich, A. 2002. 'Democracy and Development' New Political Economy 7(1): 269-281

Lehman, J. 2012. 'A Brief Explanation of the Overton Window', Mackinac Center for Public Policy, www.mackinac.org/OvertonWindow (accessed 14 July 2019).

Khoza, R. 2005. Let Africa Lead: African Transformational Leadership For 21st Century Business. Johannesburg: Vezubuntu Publishing.

Marais, H. 2011. South Africa Pushed to the Limit: the Political Economy of Change. Claremont: UCT Press .

Maza, C. 2017. 'How Trump makes extreme things look normal: Why we should worry about the "Overton Window", Vox, www.vox. com/2017/12/21/16806676/strikethrough-how-trump-overton-windowextreme-normal (accessed 5 August 2019).

Mkandawire, T. 2001. 'Thinking about developmental states in Africa', Cambridge Journal of Economics 25 (3): 289-313.

Mtimka, O. 2016. 'Is the United Front a harbinger for the 'Lula Moment' in South Africa or a pathway to a pro-working class state?' Journal of Public Administration 51 (1): 615-631.

Oxfam. 2019. 'A Tale of Two Continents: Fighting Inequality In Africa', www-cdn.oxfam.org/s3fs-public/file_attachments/bp-tale-of-two-continentsfighting-inequality-africa-030919-en.pdf (accessed 12 August 2021). 
Ndaba, B. 2018. 'Cope defends controversial partnership with AfriForum', IOL, www.iol.co.za/news/politics/cope-defends-controversial-partnership-withafriforum-18605014 (accessed 27 August 2019).

OECD. 2017. 'Income Inequality Dataset', OECD, https://data.oecd.org/ inequality/income-inequality.htm (accessed 15 August 2019).

Öniş, Z. 2016. 'Democracy in uncertain times: Inequality and democratic development in the global North and global South', METU Studies in Development 43 (April): 317-336.

Peirres, J. 2003. The House Of Phalo: A History of the Xhosa People in the Days of Their Independence. Johannesburg: Johnathan Ball.

Phillips, D. 2019. 'Brazil's former president Lula walks free from prison after supreme court ruling', The Guardian, www.theguardian.com/world/2019/ nov/08/lula-brazil-released-prison-supreme-court-ruling (accessed 17 February 2020).

Roberts, D. 2019. 'The Green New Deal', Vox, www.vox.com/energy-andenvironment/2018/12/21/18144138/green-new-deal-alexandria-ocasio-cortez (accessed 5 August 2019).

Rojas, R. 2017. 'The Ebbing 'Pink Tide: An Autopsy of Left-Wing Regimes in Latin America', New Labour Forum 26 (2): 70-82.

Slovo, J. 1990. 'Has Socialism Failed?' www.sahistory.org.za/sites/default/ files/Has percent20Socialism percent20Failed percent20by percent20Joe percent20Slovo.pdf (accessed 12 August 2019).

Terreblanche, S. 2002. A History of Inequality in South Africa, 1652-2002. Pietermaritzburg: KMM Review Publishing Company.

The Economist Intelligence Unit (EIU). 2021. 'Democracy Index 2020: In Sickness and Health?' The Economist Intelligence Unit, www.eiu.com/ public/topical_report.aspx?campaignid=democracy2018 (accessed 20 July 2019).

Veit, W. 1992. 'Democratic socialism \& social democracy: an attempt at conceptual clarification', Labour Bulletin 16 (5): 63-65.

World Bank. 2019. 'GINI index (World Bank Estimate)',World Bank Data, https://data.worldbank.org/indicator/si.pov.gini?most_recent_value_ $\mathrm{desc}=$ false (accessed 5 August 2019).

Van Niekerk, R. 2017. 'African National Congress: Social Democratic Thinking and the Good Society 1943-1962', in: E. Webster and K. Pampallis (eds), The Unresolved National Question: Left Thought Under Apartheid. Johannesburg: Wits University Press. 